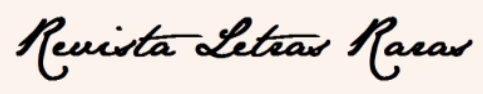

ISSN: 2317-2347 - v. 7, Edição Especial (2018).

\title{
Transmutação em Lavoura Arcaica: do romance ao filme /
}

\section{Transmutation in Lavoura Arcaica: from romance to the film}

Tânia Regina Montanha Toledo Scoparo*

\section{RESUMO}

Externamos, neste trabalho, as possibilidades de diálogos entre literatura e cinema, na obra Lavoura Arcaica, de Raduan Nassar (1975) e Luiz Fernando Carvalho (2001), respectivamente. Fazemos a leitura de alguns fragmentos, nas duas obras, romance e filme, demonstrando o processo de produção de sentido, com enfoque maior na transmutação fílmica, comparando-os. Demonstramos como Carvalho construiu o filme tendo por base o livro de Nassar. Expomos a leitura do filme, pela teoria da comunicação, mais especificamente, pelo uso da linguagem cinematográfica como produtora de sentido para a construção do filme; assim como, uma análise do narrador, das personagens, do tempo, do espaço, do enredo; como o texto revela a personagem central da narrativa, seus dramas, suas paixões. Selecionamos algumas sequências de imagens que julgamos mais importantes para fazer a análise e para o objetivo do trabalho: a transmutação fílmica.

PALAVRAS-CHAVE: Lavoura Arcaica; Romance; Filme; Transmutação.

\section{ABSTRACT}

We externate, in this article, the possibilities of dialogues between literature and cinema, in the work Lavoura Arcaica, by Raduan Nassar (1975) and Luiz Fernando Carvalho (2001), respectively. We make the reading of some fragments in both works, novel and film, demonstrating the process of producing meaning, with a higher focus on film transmutation, comparing them. We describe how Carvalho has constructed the film based on Nassar's book. We expose the reading of the film by the theory of communication, more specifically, by the use of cinematographic language as a producer of meaning for the construction of the film; so that, an analysis of the narrator, characters, time, space, plot; as the text reveals the central character of the narrative, its dramas, its passions. We select some sequences of images which are considered by us very important to carry out the analysis and for the purpose of the work: film transmutation.

KEYWORDS: Lavoura Arcaica; Novel; Film; Transmutation.

\section{Introdução}

A aproximação entre cinema e literatura tem sido frequente ao longo dos mais de 120 anos da sétima arte. Os embates frequentes entre esses dois sistemas acontecem por diversos motivos, mas, principalmente, pela natural diferença que há entre o suporte de cada um. Na transformação de um para outro, elementos de um podem ser impossíveis de adotar pelo outro, por isso essas artes sempre serão únicas, com propósitos de buscar uma forma de expressão plena.

No caso do filme Lavoura Arcaica, 2001, direção de Luiz Fernando Carvalho, um texto fortemente plástico, certas cenas são extremamente expressivas sob uma

\footnotetext{
* Professora Dra da Equipe Técnica da Secretaria Estadual de Educação Paraná - SEED; Universidade Estadual do Norte do Paraná - UENP, Brasil, taniascoparo@uol.com.br.
} 


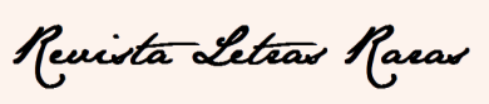

ISSN: 2317-2347 - v. 7, Edição Especial (2018).

perspectiva imagética, a sequência narrativa se apresenta como um roteiro previamente constituído e este roteiro pode ser constatado nas páginas do romance, de Raduan Nassar, publicado em 1975. A experiência artística que resulta dessa percepção é absoluta, levando o espectador a sentir, mais que compreender, por meio do confronto entre imagem e palavra, o enredamento dos relacionamentos familiares em um ambiente repressor e arcaico. O diretor transformou a narração verbal em ação visual, os intensos pensamentos abstratos da personagem principal em cenas concretas e o impacto do argumento abstrato no choque dos fotogramas. Em outras palavras, Luiz Fernando Carvalho fez cinema.

Cinema é o alimento da fantasia mais do que da razão, como Edgar Morin (1962) concebia, e nisso pode estar a explicação do vínculo entre literatura e cinema, ou seja, a ligação com o imaginário ou com a realidade do imaginário, por isso tantos autores transitam de um meio a outro. Assim, a articulação entre essas duas formas artística de expressão implica várias dimensões, não apenas a da transformação.

O romance de Nassar, que dispensa comentários em relação à estética, constitui um excelente trabalho de transmutação ${ }^{1}$ para um leitor/coenunciador ${ }^{2}$ crítico, criativo e sensível. O texto apresenta um escritor que mistura tradição e (pós) modernidade à imigração libanesa e ao espaço rural. Lavoura Arcaica é uma obra prima cujo conteúdo denso deixa transbordar o trágico e o lírico que na narrativa se entrelaçam, sensibilizando o enunciatário para a revolta e sofrimento do enunciador protagonista, André. O objetivo deste, ao revelar seu drama, é manter um diálogo com temas, problemas e valores que marcam de forma indelével a família. O enunciador revela o comportamento humano frente a uma sociedade rural arcaica. $\mathrm{O}$ romance trata do embate aos valores éticos e morais vigentes na sociedade libanesa/brasileira. Os

\footnotetext{
${ }^{1} \mathrm{O}$ mais comum é utilizarmos o termo adaptação quando nos reportamos aos filmes traduzidos de textos literários. No entanto, Roman Jakobson (1969, p. 64-65), na obra Linguística e comunicação, propõe uma terminologia para as diferentes traduções, assinalando três modos de interpretação do signo verbal. $\mathrm{O}$ primeiro modo, denominado de intralingual, consiste na tradução de um signo por outros signos da mesma língua; o segundo modo consiste na interpretação por meio de signos verbais de outra língua, denominado tradução interlingual, ou tradução propriamente dita; e o terceiro, denominado tradução intersemiótica ou transmutação, que consiste na interpretação dos signos verbais por meio de sistemas de signos não verbais. Desse modo, Jakobson apresenta a terminologia transmutação para a interpretação de signos de um meio verbal a outro, não verbal. Esse termo, portanto, é o mais apropriado nesse procedimento.

${ }^{2}$ Em semiótica, o leitor se constitui como um destinatário da comunicação e um sujeito que produz o discurso, um coenunciador capaz de desvelar os sentidos do texto de forma consciente e crítica.
} 


\section{Revista Leteas Racar}

ISSN: 2317-2347 - v. 7, Edição Especial (2018).

membros da família possuem sentimentos contraditórios de amor, paixão, desprezo, raiva e ódio.

O enredo trata do conflito de André com seu pai e com a paixão incestuosa pela irmã. Ele pertence a uma família rural engessada no tempo e no espaço descendente de libaneses. A família é constituída pelo pai, o patriarca; o irmão mais velho, Pedro; as três irmãs Rosa, Zuleika e Hunda; a mãe, mulher submissa; André, filho pródigo e sujeito da ação discursiva; Ana, irmã e a paixão de André; e Lula, o filho caçula.

O romance é dividido em duas partes intituladas "A partida" e "O retorno". Em "A partida", a narrativa mostra o encontro dos dois irmãos, André e Pedro, em um quarto anônimo de pensão, na cidade, onde André se escondeu e se refugiou após abandonar a fazenda em que vivia com a família. Nessa primeira parte da narrativa, André rememora e desnuda suas experiências, distanciado no tempo, e procura explicar ao irmão mais velho, Pedro, sua fuga do campo. Seu relato sobre si mesmo opõe-se, numa comunicação ambígua, à força poderosa do pai, que leva a vida dedicada aos trabalhos com a terra e à contrição religiosa. Os capítulos se alternam entre o momento da narração e o passado na fazenda com a família. Nesse momento presente da narração, há uma visão profunda de sua solidão, envolvida pela lascívia do corpo, da carne, em um quarto escuro de pensão. Na segunda parte, "O retorno", André, convencido pelo irmão Pedro a voltar para casa, propõe-se dialogar com o pai, expondo suas opiniões sobre a forma como ele conduz, tradicionalmente, a família. Acontece, também, em uma festa para comemorar o retorno de André, o desenlace trágico, culminando no assassinato da irmã Ana pelo pai.

Vejamos como os sentimentos conflitantes de André se articulam no processo de produção de sentido nas duas obras, romance e filme, comparando-as. O significado de um filme se faz pelo seu todo, mas é preciso compreender o amálgama do conjunto das pequenas partes para compor o significado pleno em relação a todas as partes.

\section{A construção do filme}

Roubando uma metáfora de Raduan Nassar, digo que há duas maneiras de se aproximar desse filme extraordinário. Uma delas é tentar capturá-lo de chofre, como alguém que se arriscasse a construir uma casa a partir do teto. Será inútil, naturalmente. A outra requer 


\section{Reuista Leteas Racar}

ISSN: 2317-2347 - v. 7, Edição Especial (2018).

paciência e um mínimo de tempo, o necessário para fincar os alicerces e erguer as paredes da casa. É quando se encontra a recompensa, a vivificante iluminação adquirida no contato com uma obra de arte superior (MATTOS, 2002, p. 8).

O diretor Luiz Fernando Carvalho, com tempo e paciência, reconstruiu os alicerces e as paredes da casa do romance Lavoura Arcaica de Raduan Nassar, transportando, em meio à arquitetura, o fluxo de consciência da personagem André para a linguagem do cinema e transformou o filme em uma trama enleante de poesia e massas de pura emoção, por meio de imagens, sons, música e ritmo. Buscou, na gramática fílmica, elementos que pudessem dar conta dos múltiplos tempos em que se desenrola a história de André e seu drama familiar. Como no romance, Carvalho transmuta André - o filho tresmalhado, que volta para casa e dá início a uma tragédia devido a sua paixão pela irmã - e toda sua família, como também a própria narrativa, para um caminho de "luz (harmonia, conhecimento) à escuridão (ruptura, inconsciência)". Todos entram em transe, circulam e saltam de um tempo para outro, "a imagem entorta-se, espicha-se, explode em excessos de claridade e negrume" (MATTOS, 2002, p.10). Também, como no romance, as tramas conduzem para o interior da narrativa, entornado de metáforas sensíveis, o embate entre o moderno e o arcaico, a liberdade e a opressão, a paixão e a moral, a natureza e a cultura, o tempo do pai e o tempo do filho, entre outros. Esse enredo estreou nos cinemas em $2001^{3}$, foi disponibilizado em DVD, em 2005, em seguida, uma edição especial, em 2007. Rendeu a Carvalho ${ }^{4}$ elogios da crítica e ao filme inúmeros prêmios ${ }^{5}$.

\footnotetext{
${ }^{3}$ Em 2016, o filme Lavoura Arcaica foi homenageado no Festival Internacional de Cinema do Rio pelos seus 15 anos e exibido em $35 \mathrm{~mm}$ no mesmo cinema em que estreou, no Estação Net Botafogo. Em novembro de 2016, o filme também foi homenageado e encerrou a Mostra Internacional de Cinema, em São Paulo, com a exibição do longa-metragem, um bate-papo do público com o diretor e com a presença, na plateia, do escritor Raduan Nassar, autor do romance que inspirou o filme.

${ }^{4}$ Luiz Fernando Carvalho realizou muitos trabalhos para a televisão, é diretor de novelas, minisséries e especiais. Roteirista e diretor do curta metragem A espera (1986), baseado no livro Fragmentos de um discurso amoroso, de Roland Barthes. Em 2000, lança na televisão o documentário Que teus olhos sejam atendidos, absorvido no Líbano como parte das preparações para Lavoura Arcaica - e mais tarde, esse documentário foi incluído em DVD, numa edição especial do filme - Em 2001, estreia o filme Lavoura Arcaica, seu único longa-metragem. Dirigiu as duas temporadas da minissérie Hoje é dia de Maria, em 2005. Desenvolve em parceria com a Rede Globo o "Projeto Quadrante", que transmitiu, em 2007, A pedra do reino (da obra de Ariano Suassuna) e Capitu, em 2008, (do romance de Machado de Assis, Dom Casmurro), os dois em cinco capítulos. A partir daí, dirigiu inúmeras minisséries, especiais, séries para o Fantástico. Atualmente, dirigiu a novela Velho Chico, em parceria com Benedito Ruy Barbosa. E, no início deste ano (2017), dirigiu a minissérie Dois irmãos, escrita por Maria Camargo e baseada na obra de Milton Hatoum, em dez capítulos (WIKIPEDIA).
} 


\section{Revista Leteas Racar}

ISSN: 2317-2347 - v. 7, Edição Especial (2018).

Carvalho leu o livro de Raduan Nassar e já visualizou o filme, em suas palavras:

Primeiro eu li o Lavoura... e visualizei o filme pronto, quando cheguei no final eu já sabia o filme - eu tinha visto um filme, não tinha lido um livro. Porque aquela poética é de uma riqueza visual impressionante, então eu entendi a escolha daquelas palavras que, para além de seus significados, me propiciavam um resgate, respondiam à minha necessidade de elevar a palavra a novas possibilidades, alçando novos significados, novas imagens. Tentei criar um diálogo entre as imagens das palavras com as imagens do filme. Palavras enquanto imagens (CARVALHO, 2002, p. 35).

Para criar essas imagens, Carvalho decidiu pesquisar a região, então, ele, Raquel Couto, assistente de direção, e o próprio Raduan Nassar, com uma câmera, foram ao Líbano buscar referências orientais para senti-las e transportá-las para o filme, como ele próprio explica:

Inicialmente, minha intenção era a de registrar aspectos da cultura para depois apresentá-los ao elenco e equipe. Captar todos os elementos da cultura, a culinária, os rituais religiosos, o mobiliário das casas, as vestes, registrar estas visibilidades para depois, aqui no Brasil, torna-las invisíveis, ou seja, como disse Alceu Amoroso Lima, criar uma atmosfera, um "sopro dominado pela tradição mediterrânea". Transformar o visível em invisível, não descrevendo as referências orientais, simplesmente sentir (CARVALHO, 2002, p. 36).

Ao retornar ao Brasil, fez o documentário Que teus olhos sejam atendidos, com o registro de suas pesquisas e observações do oriente. No entanto, Carvalho queria transformar o visível (documentário) em invisível, sem ser descritivo e priorizando as metáforas do livro. Criou, então, o filme.

Em Lavoura Arcaica não há um roteiro formal, o diretor usou o próprio livro de Raduan para criar as cenas, os atores leram o livro e viveram meses em uma fazenda para sentir a atmosfera, improvisar as relações das personagens dentro da própria ação de capinar, tirar leite, semear, arar a terra, e mesmo as relações entre pai e filho, filho e mãe, irmão e irmã, para, como coautores, irem construindo o texto do filme. Foi um laboratório, segundo o diretor, o que permitiu que os atores criassem um vínculo entre

\footnotetext{
${ }^{5} \mathrm{O}$ filme Lavoura Arcaica recebeu mais de 25 prêmios em diversas categorias de festivais e mostras nacionais e internacionais, entre elas, Melhor Filme, Melhor Diretor, Melhor Ator, Melhor Atriz Coadjuvante, Melhor Ator Coadjuvante, Melhor Fotografia, Melhor Trilha Sonora Original. O filme foi considerado por muitos críticos de cinema como um trabalho brilhante e um dos melhores filmes brasileiros dos últimos anos.
} 


\section{Revista Leteas Racar}

ISSN: 2317-2347 - v. 7, Edição Especial (2018).

eles e na forma de se relacionar, na descoberta das personagens, aprendiam os contextos das personagens e improvisavam em cima da literatura. As palavras foram vividas por eles, e não representadas. Carvalho embasou-se em Antonin Artaud (1993) - artista e pensador da primeira metade do século passado - e sua teoria do duplo, das sensações, por isso o laboratório com os atores, "o corpo interagia ao mesmo tempo com a terra e com o universo das relações familiares" (CARVALHO, 2002, p. 92). O ator improvisava em torno das relações com o espaço, a terra, o outro, e não com a palavra. Carvalho não queria uma narrativa descritiva, então guiou-se pela narrativa do romance, como se as palavras tivessem alma e virassem imagem "A linguagem, a meu ver, tem que ser algo invisível, pertencer ao mistério, ao jogo sensório. A minha compreensão do livro passa pela compreensão da arte como uma obra espiritual, que depende das tuas vísceras, da tua alma, das tuas antenas" (CARVALHO, 2002, p. 38). É uma narrativa de memória, circular. O diretor assinala que não há no filme um diálogo que não seja do romance, "Não há nada no filme que não seja do texto do Raduan" (Ibid., p. 45), ou seja, optou pela fidelidade na trama da história, sobretudo pela densidade dos episódios relatados.

Segundo Johnson (2003), a fidelidade absoluta praticamente não existe em nenhuma transmutação, porque essa é o resultado de uma leitura crítica e criativa da obra original. No entanto, Carvalho assim comenta a construção de sua obra:

O processo do filme como um todo tem como ponto de partida a improvisação. Havia um guia, sempre um guia mínimo para a produção, a direção de arte e o figurino tomarem conhecimento daquilo de que eu precisaria dispor em determinada cena. Mas nunca um roteiro adaptado, uma fala adaptada. Não há uma vírgula que esteja ali que não seja do Raduan, não há um artigo que não seja dele (CARVALHO, 2002, p. 44-45).

Mesmo que o diretor assim se posicione, em relação à adaptação, a leitura rigorosa executada por ele e a equipe não basta para concordar com sua afirmativa. A narrativa do romance foi inserida em outro suporte, em outra linguagem; a literatura é verbal, o cinema é icônico, e a relação entre tempo e espaço no romance ocorre de maneira bem diferente no filme. Por causa disso houve necessidade de supressões, como dos capítulos 4 e 8 do romance, e seleções, entre tantas memórias, que precisaram ser realizadas para a montagem do filme no tempo de duas horas e cinquenta minutos. 


\section{Revista Leteas Racar}

ISSN: 2317-2347 - v. 7, Edição Especial (2018).

Então, a adaptação aconteceu, mesmo que a história seja a mesma, os diálogos e a narração sejam reproduções iguais às do livro.

Além da trama, dos diálogos, o cineasta manteve do romance o olhar, o ponto de vista de André. Este nos conduzia na história, conforme elucida Carvalho:

Se eu entendo que um corte não pode ser dado aleatoriamente... eu entendo que o Lavoura... é um diário do mundo interior do André. Então quem corta é o André, então quem determina pra onde vai a câmera, se a câmera vira pra ele ou não, se passa pra cá ou se passa pra lá, quem manda nesse jogo cinematográfico é o André, quem reflete sobre esse jogo cinematográfico de luz e sombra é o André (CARVALHO, 2002, p. 62.

Dessa forma, o narrador na obra fílmica também é André. É o olho de André que narra, que reflete o acontecimento trágico. Essa questão nos encaminha às considerações de Xavier, ao esclarecer que, diante de um texto literário, precisamos compreender e ver a distinção entre "contar" e "mostrar":

Contar (tell) e mostrar (show) não perde sua clareza se reconhecermos que o mostrar aí não pode ser assumido no sentido literal, pois é o significado das palavras que produz o "ver" (que é, em verdade, um imaginar que ativamos com prazer). A "cena" no romance não é algo palpável como a cena, em versão literal, própria ao teatro e ao cinema, mas isso não impede que se entenda, na literatura, a oposição entre tell e show como escolhas do escritor. Da mesma forma, dizemos que a câmera "mostra", mas há toda uma literatura voltada para o seu papel como narrador no cinema, que nos permite dizer que a câmera narra (tell), e não apenas mostra. Isso porque ela tem prerrogativas de um narrador que faz escolhas ao dar conta de algo: define o ângulo, a distância e as modalidades do olhar que, em seguida, estarão sujeitas a uma outra escolha vinda da montagem que definirá a ordem final das tomadas de cena e, portanto, a natureza da trama construída. Portanto, dizer que um filme "mostra" imagens é dizer pouco e muitas vezes elidir o principal (XAVIER, 2003, p. 73-74).

Assim, segundo esse autor, a câmera é a narradora de filmes, e, pensando dessa forma, no filme, pelos olhos de André, ela narrou de diferentes maneiras pois sugeriu, mostrou, antecipou fatos e também apresentou suas reminiscências e memórias, com o intuito de expressar como se sentia e sua maneira de perceber o mundo.

Consoante Xavier, o discurso narrativo efetua a distinção entre a cena aparente e a construção que possibilita a sugestão, porque, sem nomear uma "ação ou fato, posso deixar subentendida a sua ocorrência por meio dos saltos do tempo - as elipses narrativas. Em 


\section{Reuivta Leteas Parar}

ISSN: 2317-2347 - v. 7, Edição Especial (2018).

alguns casos, elas correspondem a um gesto de encobrir, deixar de fora da vista o que quebraria o decoro da representação" (XAVIER, 2003, p. 74).

Nesse sentido, Carvalho apropria-se de diversos recursos da linguagem cinematográfica. Para demonstrar a produção de sentido que esses recursos possibilitam, faremos uma leitura do filme por meio de algumas sequências de cenas. Essas sequências foram escolhidas para análise devido à sua importância na narrativa. Não que outras, não contempladas, não sejam importantes, mas, devido ao espaço para publicação deste artigo, e em meio a tantas, selecionamos algumas que acreditamos poder dar conta do objetivo aqui: mostrar a transmutação fílmica.

\section{Leitura das obras e suas relações: a transmutação fílmica}

A narrativa do romance se inicia com André dentro de um quarto de pensão. Ao fundo, ouve-se um som de apito de trem, anunciando sua chegada à cidade. A cena é o início do filme e tem duração de $5 \mathrm{~min} 45 \mathrm{seg}$. Observemos as imagens:
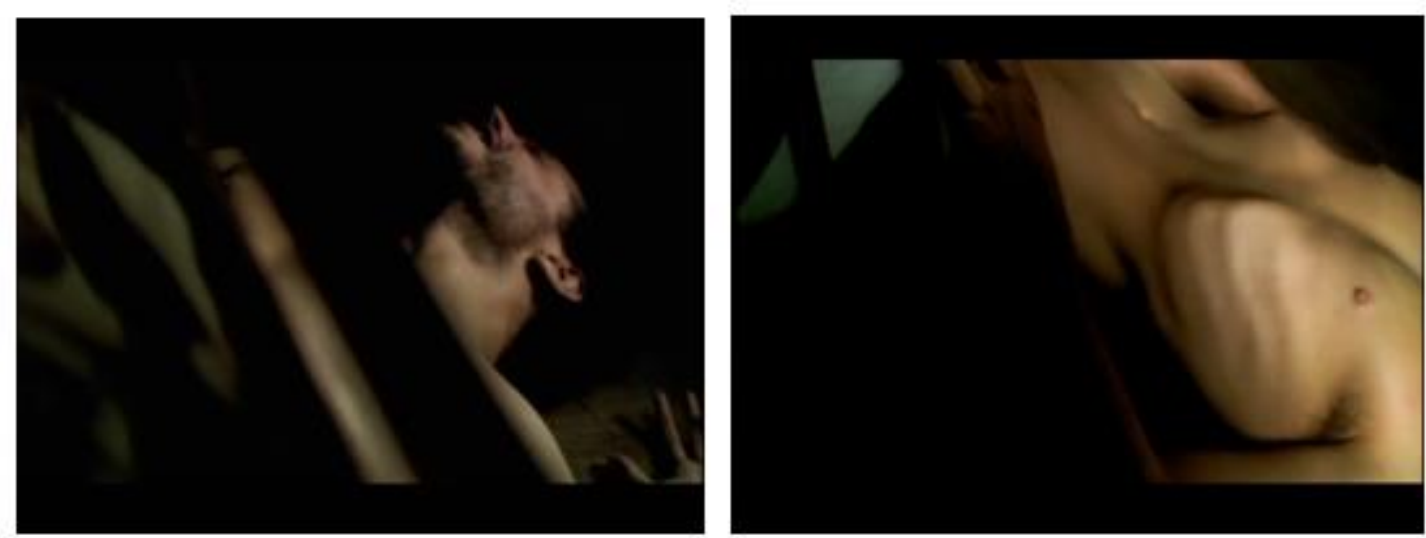

Figuras. 1 e 2 - Travelling horizontal em André

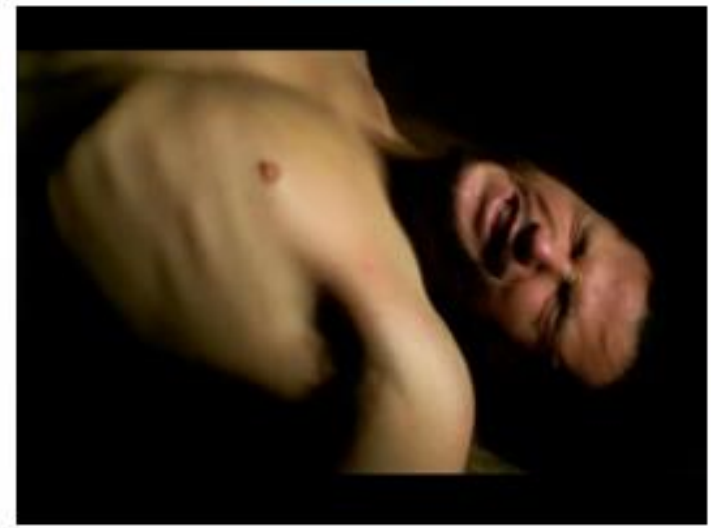

Figura 3 - Momento do apito do trem

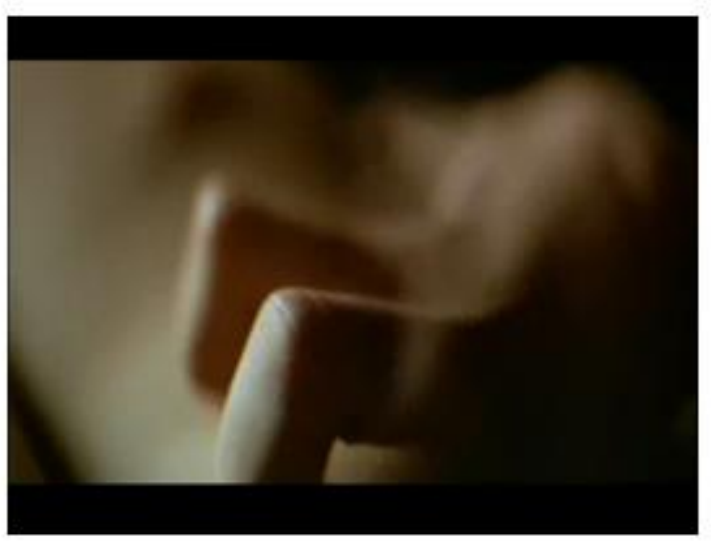

Figura 4 - Mãos em transe 


\section{Penista Leteas Paras}

ISSN: 2317-2347 - v. 7, Edição Especial (2018).

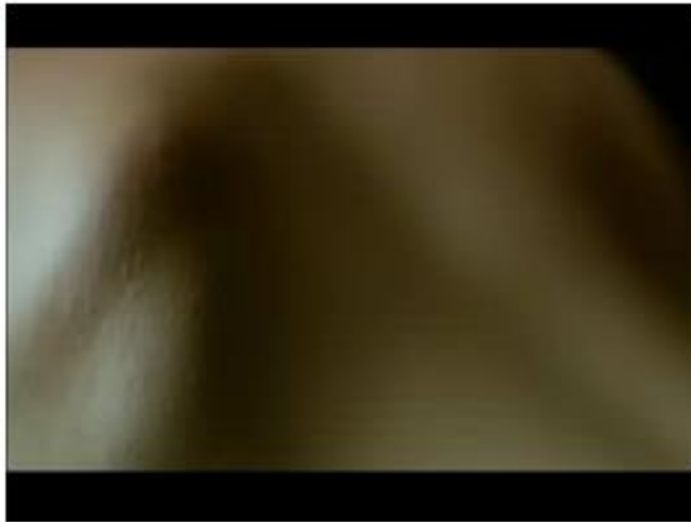

Figura 5 - Ritmo do peito

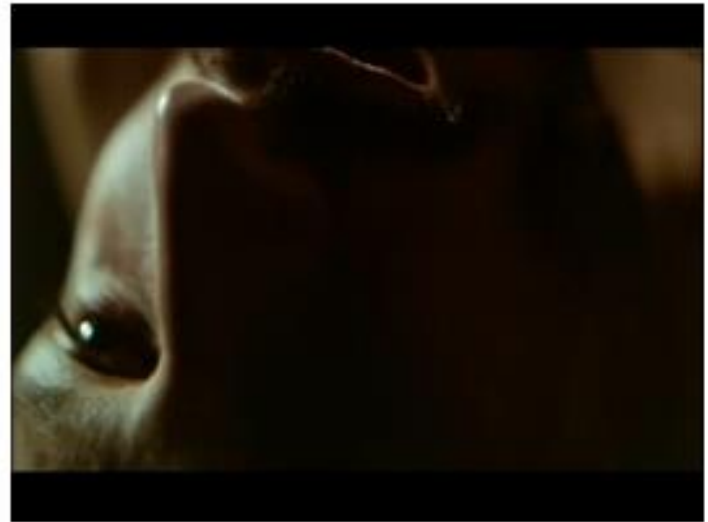

Figura 6 - Olhar

Fonte das imagens: DVD Lavoura Arcaica, 2001.

A câmera, lentamente, revela o corpo de André. Ele está no assoalho do quarto se masturbando, o corpo está em êxtase, a câmera, lentamente, em travelling horizontal, figs 1 e 2 , o enquadra em plano conjunto, primeiro plano, plano detalhado ${ }^{6}$. A luz do crepúsculo reflete e partes do quarto estão em sombras. Esses três planos estão articulados de forma simples e ao mesmo tempo inquietante. $\mathrm{O}$ primeiro enquadra André no ambiente do quarto e lentamente a lente da câmera vai se fechando e, em primeiro plano, revelando partes do corpo de André. Há um detalhe da mão dele em cima do corpo, os dedos retorcidos, fig. 4, alguns segundos nesse detalhe, depois, o peito, fig. 5, também alguns segundos, peito acelerado, principalmente quando surge o som do apito do trem, a câmera se fecha mais ainda e fica bem próxima nesse detalhe e,

${ }^{6}$ É na articulação dos planos que se deve produzir um sentido lógico e coerente para o texto visual. Xavier (2005, p. 28), ao tomar os conceitos de decupagem clássica, classifica quatro planos, que serão demostrados a seguir:

- Plano Geral: Insere o sujeito em um ambiente, eventualmente dando uma ideia das relações entre eles. Mostram cenas amplas, todo o espaço da ação. Abrange um campo maior de visão.

- Plano Médio ou de Conjunto: Mostra o conjunto de elementos envolvidos na ação (figuras humanas e cenário), principalmente em interiores (uma sala por exemplo).

- Plano Americano: Corresponde ao ponto de vista em que as figuras humanas são mostradas da cabeça até a cintura aproximadamente, em função da maior proximidade da câmera em relação a ela.

- Primeiro Plano (close-up): A câmera, próxima da figura humana, focaliza um detalhe, um rosto, por exemplo. (Há uma variante chamada primeiríssimo plano, que se refere a um maior detalhamento - um olho, ou uma boca ocupando toda a tela).

A câmera, assim, além de se deslocar no espaço, recorta-o. Ela filma fragmentos do espaço, que podem ser amplos, por exemplo, um campo, ou restritos, um rosto.

Há, também, os movimentos de câmera chamados travelling e panorâmica:

- $\quad$ Travelling Deslocamento da câmera num determinado eixo.

- Panorâmica: Rotação da câmera em torno de um eixo, vertical ou horizontal, sem deslocamento do aparelho. 


\section{Revista Leteas Racar}

ISSN: 2317-2347 - v. 7, Edição Especial (2018).

finalmente, o rosto de André, fig. 6, convulsionado, câmera parada quase dois minutos nesse rosto, enfatizando seu desespero interior mascarado por um prazer momentâneo. Concomitantemente a esse processo, o som do apito do trem aumenta de intensidade, e André chega ao êxtase. Não é um rosto feliz pelo prazer recebido, mas um rosto amargurado, em sofrimento. Os detalhes nos olhos, tristes, muito tristes, refletem dor, solidão. Em seguida, chega seu irmão mais velho, Pedro, à pensão. O diretor utilizou uma estrutura em contraponto ${ }^{7}$ para narrar essa cena. Se a ação de masturbação indica prazer, as mãos e o rosto de André expressam sofrimento. Na sua leitura diegética, o espectador participa dessa construção narrativa.

Nessa sequência, o diretor privilegia as sensações de André, para isso ele precisa usar a câmera sem parecer que a está manuseando, para o espectador sentir que são os olhos da personagem voltados para dentro de si mesmo. Então, ele estabelece um jogo narrativo, cinematográfico, utilizando o recurso da linguagem para criar uma sintaxe que organize seu momento particular, emocional, pois, segundo Carvalho (2002, p. 63) o filme precisava, para ter sentido, reencontrar a vida, "as imagens deveriam surgir de dentro, a narrativa é de dentro para fora, é este o fator que sustenta a narrativa", e, dessa forma, o espectador também é convidado a partilhar aquele estado alterado. Esse momento de André não é só um transe de gozo, toda sua carga emocional conturbada está sendo representada nesse ato de masturbação, vários conteúdos de ordem pessoal estão sendo acionados e jorrados nesse êxtase.

Como no romance, nessa sequência, foi construída uma síntese dramática de todo o filme, pois sugere uma possessão, do corpo em delírio, todo interior de André está representado nas imagens que o compõem. Tanto livro como filme é um tipo de diário, conforme Carvalho (2002), então a câmera deve ser uma caneta ou um olho para registrar e/ou revelar a personagem através de seu estado emocional. Para isso, o diretor usou uma câmera subjetiva com rotação ao longo do eixo horizontal, imitando o movimento dos olhos do espectador enquanto examina a cena. Esse movimento está ligado ao ponto de vista de André. O prelúdio de seu êxtase maximiza a sensação de sua vulnerabilidade. Os planos de detalhes das mãos e do rosto de André comprovam que, no cinema, o exercício de concentração dramática possui estratégias singulares. Esses

\footnotetext{
${ }_{7}$ Contraponto é o confronto entre dois processos expressivos com o mesmo conteúdo significativo, mas em dois registros plásticos diferentes.
} 


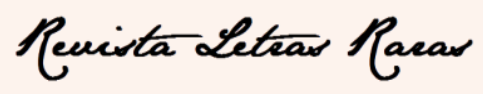

ISSN: 2317-2347 - v. 7, Edição Especial (2018).

planos permitem ao espectador construir por antecipação o cerne da história: o indivíduo em embate consigo mesmo, com o tempo (explicado mais adiante), e depois, no decorrer da narração, esse embate se estende, principalmente, ao pai, mas também, à família, e na convivência com eles, assim, reunião e exclusão, ordem e desordem, reconciliação e conflito são situações frequentes que se articulam no desenrolar da narrativa.

O cineasta compreende muito bem o recurso da cor. Por isso mesmo, a luz obedece a uma estratégia. A iluminação ajuda a compor esse quadro. Ela é expressiva e contribui para detalhes da narrativa, revelando o grau de obsessão de André. A história de Lavora Arcaica é tecida pelas diferenças, pelos contrastes humanos. A sombra escura é percebida em vários momentos no quarto de pensão. Conforme o tempo vai passando, ao decorrer da noite, o preto contamina o espaço, como uma metáfora da escuridão em que a personagem se encontra, seu mundo interior. No início da sequência, o corpo de André aparece com vestígios de luz embebidos pelas sombras. O claro-escuro indica o motivo sombrio que se opera nele. Ao mesmo tempo ela é realista, tão naturalmente na cena que o espectador não percebe que ela é um recurso da linguagem do filme, pois está composta na cena como se viesse da iluminação natural de um crepúsculo. Para esse efeito, há uma luz principal, chamada de luz-chave, que fica, geralmente, de um dos lados da câmera e é dirigida ao objeto a ser iluminado; há também as luzes atenuantes, que removem as sombras causadas pela luz-chave e moldam André para acrescentar detalhes e dar mais realismo; e uma contraluz, que define o contorno de André e o separa do pano de fundo, aumentando a ilusão de uma imagem tridimensional. Esse jogo com vários tipos de luz é expressivo e visa explorar as sombras para iluminar partes da cena, dando uma impressão de que algo está fora de ordem, obscuro.

Outro recurso importante utilizado nessa sequência é o som. Normalmente, nos filmes, evidenciam-se ruídos diversos, como os diálogos, a música, os ruídos/efeitos, que combinados, contribui com novas e variadas possibilidades para a gramática fílmica. Deleuze explica as variadas implicações trazidas pelo som, o que nos auxilia a compreender casos em que o som se torna parte da estrutura do filme:

Às vezes é lembrado que não há apenas uma fita sonora, mas pelo menos três grupos: falas, ruídos, músicas. Talvez até seja preciso 


\section{Reuista Leteas Racar}

ISSN: 2317-2347 - v. 7, Edição Especial (2018).

distinguir um número maior de componentes sonoros: [...] É evidente que estes diferentes elementos podem rivalizar, se combater, suprir, recobrir, transformar. [...] Isto poderia levar-nos a crer, conforme uma tese fundamental de $\mathrm{Fano}^{8}$, que já há um único continuum sonoro, cujos elementos só se separam em função de um referente ou de um significado eventuais, mas não de um "significante". A voz não é separável dos ruídos, dos sons que a tornam, às vezes, audível: é essa, aliás, a segunda grande diferença entre os atos de fala cinematográficos e os teatrais. [...] Em vez de invocar o significante e o significado, poderíamos dizer que os componentes sonoros só se separam na abstração de sua audição pura. Mas, na medida em que são uma dimensão própria, uma quarta dimensão da imagem visual (o que não quer dizer que se confundem com com um referente ou significado), formam então todos juntos um único componente, um contínuo. E é na medida em que rivalizam, se recobrem, se atravessam, se cortam, que traçam um caminho cheio de obstáculos no espaço visual, e não se fazem ouvir sem serem também vistos, por si mesmos, independentemente da fonte, ao mesmo tempo que fazem que a imagem seja lida, mais ou menos, como uma partitura (DELEUZE, 2005, p. 277-278).

Dessa forma, entendemos que o som se liga a uma imagem, transformando-a, elaborando uma nova dimensão; ao mesmo tempo, compreendendo vozes, falas, músicas, ruídos, que formam um todo inseparável, ligado à estrutura do filme, só se pode entendê-lo enquanto contínuo sonoro. Continuidade, timbre, fluência, misturam-se à estrutura do filme, arquitetando os sons dentro dele, e são usados em função de necessidades atinentes à faixa sonora. Esse é o conceito de contínuo sonoro empregado por Deleuze e que se aplica aos filmes.

Assim, na construção de Lavoura Arcaica, o contínuo sonoro é um trabalho artístico $^{9}$, uma vez que este e o processo narrativo se relacionam e se compartilham. Nesse sentido, o som fílmico está quase sempre em correlato com uma "percepção visual, até mesmo nos casos-limite em que a tela fica escura. A percepção fílmica é,

\footnotetext{
8 Manzano (2003, p. 111 ) explica quem é Michel Fano: "renomado teórico e técnico de som de cinema, definido por alguns como "poeta do som". Crítico a respeito de uso do som como mero pontuador da ação no cinema tradicional, Fano acredita que, para usar uma linguagem mais precisa e menos barroca, a trilha sonora pode ser "o terceiro discurso", compondo a significação global de um filme em pé de igualdade com as imagens e o texto. É diretor do Departamento de Som da FEMIS (École Nationale des Métiers des Images et du Son), em Paris, conhecido também por trabalhos marcantes nas trilhas sonoras de filmes de Alain-Grillet".

${ }^{9}$ O filme M, o Vampiro de Düsseldorf, de Fritz Lang, realizado em 1931, nos primórdios do advento do cinema sonoro, "é tido como um dos primeiros filmes a utilizar o som dramaticamente dentro da narrativa. Tendo sido também o primeiro filme sonoro de Fritz Lang, $M$ foge à prática inicial do cinema sonoro de reproduzir todos os sons presentes na cena, ao optar por uma seleção sonora. Ou seja, no filme há a escolha de quais sons são relevantes e como seu uso em determinadas situações e de modo específico pode aumentar o impacto dramático das cenas e do filme com um todo" (MANZANO, 2003, p. 143).
} 


\section{Revista Leteas Racar}

ISSN: 2317-2347 - v. 7, Edição Especial (2018).

portanto, áudio(verbo)visual e faz intervir numerosas combinações entre sons e imagens: redundância, contraste, sincronismo ou dessincronização, etc" (AUMONT, 2007, p. 276) ${ }^{10}$. Dessa forma, desempenha uma função narrativa e fornece acompanhamento realista nesse início de filme. O diretor utilizou o som de um apito para trazer a imagem do trem, uma imagem agônica de André, que está associada ao sentimento trágico do que aquele trem pode sugerir em sua vida, conforme corrobora Manzano (2003, p. 36) "um som inicialmente associado a uma imagem pode vir a possibilitar novas associações mais adiante no filme". Carvalho realizou uma ideia sensorial do som que prenunciava a chegada do irmão na pensão, um recurso utilizado como contraponto realista off (o som off, que está fora de campo) com valor simbólico em relação à imagem, aumentando o coeficiente de autenticidade na representação do momento vivido pela personagem.

O preenchimento do extracampo pelo som e seu uso inteligente complementa a imagem visual, como é o caso da utilização, por Carvalho, do som off (ou voz off). Há diferentes maneiras de esse som ser representado dentro da estrutura fílmica, conforme Deleuze, teórico que sintetiza eficazmente a presença (oculta) do som já dentro do conceito cinema:

Ora, o extracampo remete a um espaço visual, que prolonga naturalmente o espaço visto na imagem: então o som off prefigura aquilo de onde ele provém, algo que logo será visto, ou que poderia ser visto na imagem seguinte. [...] Esta primeira relação é a de um conjunto dado com um mais vasto que o prolonga ou engloba, mas de mesma natureza. Ora, ao contrário, o extracampo atesta uma potência de outra natureza, excedendo qualquer espaço e qualquer conjunto: remete desta vez ao Todo que se exprime nos conjuntos, à mudança que se exprime no movimento, à duração que se exprime no espaço, ao conceito vivo que se exprime na imagem, ao espírito que se exprime na matéria. Nesse segundo caso, o som ou a voz off, consistem antes em música, e em atos de fala muito especiais, reflexivos e não mais interativos (voz que evoca, comenta, sabe, dotada de uma onipotência ou de uma forte potência sobre a sequência das imagens). [...] ... mas tanto uma quanto outra são estritamente inseparáveis da imagem visual. [...] A diferenciação dos aspectos no

${ }^{10}$ Há uma série de estudos sobre o som. Christian Metz, Rick, Altman, Michel Marie, Francis Vanoye, Marcel Martin, Gilles Deleuze, entre outros, dedicam à trilha sonora cuidadosa atenção, como a da imagem. Esse interesse advém dos eventos tecnológicos (SILVESTRE, 2004). Stam diz sobre o 'atraso' no estudo do som, mesmo tendo "[...] estado presente desde os seus primórdios, mas foi analisado com o devido rigor tão-somente nos anos 80 e 90 (com raras exceções, como Composing for the film, de Eisler e Adorno, de 1944). Parte desse atraso é o resultado, quem sabe, da visão convencional do som como mero acessório ou suplemento da imagem" (STAM, 2003, p. 238). 


\section{Revista Leteas Racar}

ISSN: 2317-2347 - v. 7, Edição Especial (2018).

contínuo sonoro não é uma separação, mas uma comunicação, uma circulação que está sempre reconstituindo o contínuo (DELEUZE, 2005, p. 279).

Importante diferenciar som off - o som encontra-se fora de cena, mas está referenciado nela - de som over - a fonte sonora está integrada na cena, porém não apresenta referência material nela; como exemplo, nos casos de filmes documentários, que são essencialmente descritivos. Importa que, mesmo com essa diferenciação, esses sons estão sempre ligados à imagem visual "e sempre associados ao contínuo sonoro, constituindo-o" (MANZANO, 2003, p. 114).

É possível obter efeitos sonoros que possuem valor simbólico. O recurso técnico do som off, no filme, tornou possível a Carvalho criar o que se chama, na linguagem do cinema, de metáfora fílmica, ou seja, "a justaposição por meio da montagem de duas imagens que, confrontadas na mente do espectador, irão produzir um choque psicológico, choque este que deve facilitar a percepção e a assimilação de uma idéia que o diretor quer exprimir pelo filme" (MARTIN, 2003, p. 93). No caso aqui exposto, o diretor comparou "um conteúdo visual e um elemento sonoro, destinando-se este último a sublinhar a significação do primeiro pelo valor figurado e simbólico que possui; de certo modo, o som entra em contraponto mais ou menos direto com a imagem" (MARTIN, 2003, p. 117), assim a respiração, ofegante e angustiante de André, é aproximada ao resfolegar de um trem enquanto o apito acompanha seu êxtase. Assim, o som e o trem tiveram um valor simbólico, adquirindo, para além do significado da imagem e de suas aparências realistas e expressivas, um valor mais amplo e profundo, que resume a sequência em imagem-síntese de todo o filme.

Exploraremos melhor esse conceito de metáfora e símbolo para a produção de sentido em um filme. Para entendermos uma imagem, muitas vezes precisamos confrontar as imagens que vêm depois ou com as que já passaram. Tudo no cinema é significação, tudo tem sentido e produz reflexão, por exemplo, "o mar pode simbolizar a plenitude das paixões (A noite de São Silvestre, Pick) [...] É por isso que a maior parte dos filmes de qualidade admite vários níveis de leitura, conforme o grau de sensibilidade, imaginação e cultura do espectador" (MARTIN, 2003, p. 92). O filme sugere para além da ação visível na tela. Nesse processo, o símbolo desempenha um papel muito importante na sétima arte. Sua utilização, consoante Martin: 


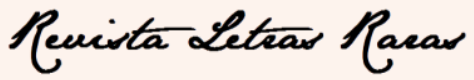

ISSN: 2317-2347 - v. 7, Edição Especial (2018).

Consiste em recorrer a uma imagem capaz de sugerir ao espectador mais do que lhe pode oferecer a simples percepção do conteúdo aparente. A propósito da imagem fílmica é possível, com efeito, falarmos de um conteúdo aparente e um conteúdo latente (ou ainda de um conteúdo explícito e um conteúdo implícito), sendo o primeiro direta e indiretamente legível e constituindo o segundo (eventual) o sentido simbólico que o diretor quis dar à imagem ou aquele que o espectador reconhece por si mesmo (grifos do autor) (MARTIN, 2003, p. 93).

Dessa forma, o símbolo substitui algo (pessoa, objeto, gesto, acontecimento, etc) por um signo, fazendo surgir uma segunda significação, "seja pela aproximação de duas imagens (metáfora), seja por uma construção arbitrária da imagem ou do acontecimento que lhe confere uma dimensão expressiva suplementar (símbolo propriamente dito) ${ }^{11}$ (MARTIN, 2003, p. 93) (grifos do autor). Há símbolo propriamente dito, portanto, quando "a significação não surge do choque de duas imagens, mas reside na imagem enquanto tal" (Ibid., p. 97) (grifo do autor).

Neste cenário criado por Carvalho, notamos que a metáfora criada entre o trem e o som do apito faz sentido e remete prolepticamente para o que depois se saberá: o contraponto entre imagem e som revela a angústia interior de André, e antecipa a chegada do irmão, que governará os acontecimentos para um final trágico, portanto são elementos importantes para a compreensão plena da obra e inserem-se de forma significativa na estrutura do filme.

Encontramos nesta sequência uma associação muito explícita entre ação e reação em função do som e da montagem. O uso da câmera subjetiva, revelando o ponto de vista de André, é outro suporte da sequência, contribuindo para sua construção. Trata-se de uma sequência em que o som sugerido de certa forma conduz a ação. A montagem é determinada por dois aspectos: os elementos sonoros (respiração, apito do trem) e pelo ponto de vista (câmera subjetiva). Soma-se a isso a ação do ator, reagindo à referência sonora. "No geral, são elementos sonoros, marcando a presença de um algo mais" (MANZANO, 2003, p. 142).

Enfim, o aperfeiçoamento dos recursos fílmicos, aliado à articulação cada vez mais complexa permite que o cinema se constitua num expressivo discurso audiovisual, comprovadamente nessa cena inicial. Carvalho não realizou uma adição de palavras ou

${ }^{11}$ Por analogia com as figuras da retórica clássica, metáfora é a substituição de uma palavra por outra, quando há uma relação de similaridade entre o termo de partida (substituído) e o de chegada (substituinte) (FIORIN, 1999, p. 86). 


\section{Pevista Leteas Racas}

ISSN: 2317-2347 - v. 7, Edição Especial (2018).

de ruídos, mas construiu uma forma. Existe, no filme, um ritmo de som, assim como o da imagem. Como ratifica Merleau-Ponty, o filme visual não consiste em:

[...] mera fotografia em movimento de uma peça teatral, e como a escolha e o agrupamento das imagens constituem, para o cinema, um meio de expressão original, de idêntica maneira, o som, no cinema, não é simples reprodução fonográfica de ruídos e de palavras, porém comporta uma determinada organização interna que o criador do filme deve inventar (MERLEAU-PONTY, 1983, p. 112).

E, assim, Carvalho conseguiu armar paralelismos relevantes nessa cena porque estava atento à necessidade de trabalhar com precisão as principais informações dramáticas para que o espectador fosse perfeitamente introduzido na trama, podendo, mais tarde, participar ativamente de um drama armado meticulosamente.

\section{A construção da narração}

Carvalho se vale do recurso da narração, por meio de um ponto de vista autodiegético interno, quando André assume o relato e expõe os fatos vividos, evocações da memória e das reminiscências. A subjetividade na narrativa fílmica é manifestada, principalmente, no monólogo interior em que André se recolhe em sua intimidade e relata a impressão dos fatos da história de vivência com a família; dessa forma, caracteriza-se pelo equilíbrio entre "[...] a palavra com o pensamento fluente, espontâneo, reflexivamente encadeado do personagem, seja o encadeamento intelectual e lógico, seja afetivo e ilógico, no rastilho de imagens ou idéias associadas" (NUNES, 1995, p. 64).

Há, como no romance, uma articulação temporal complexa, pois André presentifica o passado, ora retomando o passado na fazenda com a família, ora se apropriando de movimentos retrospectivos e introspectivos, como também alternância, conforme sua particularidade. Bourneuf e Quellet (1976) assinalam que o tempo é a essência da vida e pode ser definido pelo tempo cronológico, marcado pela passagem dos ponteiros do relógio, ou pelo tempo subjetivo, que remete à experiência pessoal, um tempo que envolve “[...] um fenômeno de ordem psíquica: pressentimentos, antecipações, reminiscências ou simples associações de imagens que reenviam a outro 


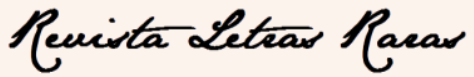

ISSN: 2317-2347 - v. 7, Edição Especial (2018).

tempo" (BOURNEUF; QUELLET, 1976, p. 183). Isso é muito claro na obra dirigida por Carvalho.

O filme assenta-se na representação da ação, organizada numa sucessão de fatos ao longo do tempo, que se dá por meio do discurso, que por sua vez é uma sucessão de enunciados postos em sequência de imagens filtradas pela câmera. Dessa forma o tempo é a condição da narrativa; no cinema, como já vimos, o tempo é preenchido com o espaço ocupado por uma sequência de imagens, condensando o curso dos fatos, pois "contém o antes que se prolonga no durante e no depois, significando a passagem, a tensão do próprio movimento representado em imagens dinâmicas" (PELLEGRINI, 2003, p. 18). Assim, os domínios entre espaço imagético (percebido) e tempo (sentido, imaginado) não se distinguem, um não existe sem o outro. Ademais, a câmera cinematográfica

mostra que a noção do tempo que passa é inseparável da experiência perceptiva visual, a qual não mais repousa na perspectiva única do indivíduo que vê: a câmera é uma espécie de olho mecânico finalmente livre da imobilidade do ponto de vista humano, para o qual não mais convergem todos os pontos de fuga, como quando se via uma pintura ou uma fotografia (PELLEGRINI, 2003, p. 19).

Isso reflete sobremaneira na narrativa fílmica, por meio de técnicas de montagem e de colagem. Recursos como o fade-in, o fade-out, o flashback, entre outros, imprimem marcas temporais no filme. São técnicas fílmicas ligadas aos cortes nas cenas. O corte é a passagem de um plano para outro, uma realização material do tempo cinematográfico. Por meio deles, o diretor pode lidar com o tempo de diferentes maneiras.

A impressão do tempo, no filme, também é marcada pelas vozes que atualizam o discurso. São estas vozes que se alternam na construção da narrativa: a voz de André (do ator Selton Mello), a voz do pai (do ator Raul Cortez) e a voz do narrador em off $f^{2}$

\footnotetext{
${ }^{12} \mathrm{~A}$ voz em off é aquela que vem de uma fonte exterior ao quadro, conforme já explicado anteriormente. Consoante Manzano (2003, p. 113), os sons estão associados à imagem visual modificando-a. Uma vez que estejam dentro do filme, os sons devem ser entendidos em função do conjunto, formando um único componente, um "contínuo". Desenvolvendo-se no tempo - tanto tempo interno da ação fílmica como também um tempo maior, absoluto - o som traz implicações sobre o espaço fílmico. Deleuze coloca as novas possibilidades quanto ao uso de voz off como preenchimento do extracampo e como função de nãoredundância: "Se o contínuo (ou componente sonoro) não tem elementos separáveis, isso não o impede de se diferenciar a cada momento, segundo duas direções divergentes que exprimem sua relação com a imagem visual. Essa dupla relação passa pelo extracampo, na medida em que este pertence plenamente à imagem visual cinematográfica. Claro, não é o sonoro que inventa o extracampo, mas é ele que o povoa e
} 


\section{Reuista Letear Racar}

ISSN: 2317-2347 - v. 7, Edição Especial (2018).

(do diretor Luiz Fernando Carvalho). As personagens dialogam e presentificam a narrativa. A voz do narrador não só narra sua história como também reflete sobre ela, assim como o narrador do romance. A voz off do narrador cria o lirismo que há no romance.

As lembranças da personagem André são revividas por meio do fluxo de consciência, não há uma ordem temporal, no entanto um eixo cronológico organiza os diferentes tempos, que é a visita de seu irmão Pedro na pensão para levá-lo de volta à fazenda, sua casa. Na pensão, ele revive sua história, entremeando tempos e memórias, sem uma progressão. O encontro com o irmão remonta sua história, ata sua partida e seu retorno ao lar.

Em todo o filme houve montagens que subverteram a ordem cronológica em proveito de uma temporalidade subjetiva e dramática, onde presente e passado se mesclavam continuamente. $\mathrm{O}$ complexo espaço-tempo modela o universo fílmico e o tempo é o elemento que estrutura e determina a narrativa cinematográfica, como já exposto. O tempo em Lavoura Arcaica teve o que Martin (2003, p. 226-227) chama de razões dramáticas, ou seja, o uso constante de flashback, colocando o espectador como confidente das ações, valorizando o conteúdo humano e a solidez de sua construção, contribuindo para a "criação da unidade de tom: retira dos acontecimentos sua aparente disponibilidade e revela seu sentido profundo, indicando ao espectador o rumo que a ação irá tomar" (grifo do autor). Esse recurso concentra o interesse na trajetória da personagem e na sua construção dramática. Também há o recurso de razões psicológicas, pois o filme está centrado num único personagem que evoca suas memórias e concentra nele o drama. Assim, ao "atingir o paroxismo do seu drama, o herói revive as circunstâncias que o levaram a uma situação de desespero e solidão" (MARTIN, 2003, p. 227), como é o caso de André. As transições entre presente e passado são feitas num elaborado procedimento técnico de travelling para a frente e fusão entre dois planos.

preenche o não-visto visual com uma presença específica. [...] Desde o início, o problema do sonoro era: como fazer para que o som e a fala não sejam mera redundância do que se vê? Este problema não negava que o sonoro e o falado fossem um componente de imagem visual, ao contrário: era na qualidade de componente específico que o som não devia ser redundante com o que era visto. $\mathrm{O}$ célebre manifesto soviético já propunha que o som remetesse a uma fonte no extracampo, sendo assim um contraponto visual e não o duplo de um ponto de vista: o ruído das botas é justamente mais interessante quando elas não são vistas. [...] Em suma, o sonoro sob todas as suas formas vem povoar o extracampo com a imagem visual, e realiza-se ainda melhor nesse sentido como componente dessa imagem: no plano da voz, é o que se chama voz off,_cuja fonte não é vista" (DELEUZE, 2005, p. 278-279). 


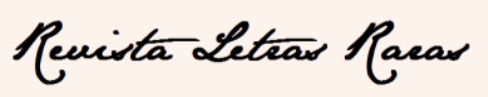

ISSN: 2317-2347 - v. 7, Edição Especial (2018).

Nesse sentido, o uso de flashback é recorrente na narrativa fílmica. A trama da história de Lavoura Arcaica é composta de retomada do passado, ou seja, uma versão particular e individual do modo de André perceber os acontecimentos anteriores de sua vida ao presente imediato. Há, assim, uma perspectiva que se mobiliza ao mostrar ou sugerir as cenas apresentadas na película e as ações presentificam o passado. Os fatos contados ao irmão no quarto da pensão atualizam o tempo e ajudam a compor o quadro narrado por André.

Como no romance, há sempre um deslocamento temporal no filme, dos fatos lembrados e narrados por André. Esses fatos tornam a obra uma narrativa densa, cheia de fragmentos, nos quais o espectador tem que ficar atento para não se perder. Há um jorro das palavras do passado (memória) e do presente, seu discurso não segue uma ordem cronológica, mas é ordenado pela desordem, sem cronologia. O ritmo contínuo se dá pelos tempos da ação e da rememoração, onde o passado se insufla no presente e o presente retorna pelo passado, os eventos se superpõem, em uma associação livre, compondo um hibridismo temporal no qual se instala como um tema na trama. Há então uma mistura de reminiscências da infância, aglutinando-se com a juventude em casa e fora de casa, na pensão.

André é uma personagem complexa e sua construção se dá à medida que seus conflitos internos e externos vão se desenrolando. O pai é o antagonista da história, um sujeito opressor, arcaico, com leis rígidas, apregoa o equilíbrio, pautado pelo controle das paixões. André é movido pela necessidade de lutar contra essa força opressora, faz um percurso, na trama, para tentar romper com a tradição do pai. Busca em Ana uma forma de liberdade. Instaura-se uma tensão entre pai e filho que culmina no incesto. $\mathrm{O}$ próprio tempo é um inimigo de André, um tempo que não volta, que é irrecuperável, o tempo do narrador, do inconsciente. Esse tempo acaba por se tornar, também, um opositor entre pai e filho. No pai, há um tempo movido pela superioridade, típico do autoritarismo, das tradições de sua cultura árabe, de conservar os costumes; no filho, o tempo é ágil, é o presente, moderno, movido pelas mudanças, com característica idealista, portanto há um embate constante entre o discurso autoritário (sermões e parábolas) e o anárquico (confuso, caótico), ancorado no tempo.

Vejamos as sequências de duas festas que ocorreram nas histórias do romance e do filme para explicitar esse tempo da narrativa. 


\section{Reuista Letear Racar}

ISSN: 2317-2347 - v. 7, Edição Especial (2018).

No início do romance, capítulo 5, André narra ao irmão a festa que acontecia aos domingos para unir as famílias e os vizinhos "era no bosque atrás da casa" (NASSAR, 1989, p. 28). O cheiro de carne assada se perdia entre as muitas folhas das árvores e a música soprada por uma flauta juntava as famílias em uma grande roda de dança. André assiste a tudo isso "recolhido junto a um tronco mais distante" (Ibid., p. 29). Surge Ana nas suas memórias "essa minha irmã, como eu, mais que qualquer outro em casa, trazia a peste no corpo" (Ibid., p. 30). Ao final de seu discurso, a mãe o procura para tentar levá-lo à festa.

Os verbos nessa passagem estão no pretérito imperfeito, aludindo a uma situação que se repete, é um passado de ação que continua. André retrata uma família que era unida, em uma estrutura perpetuada, como nos discursos que o pai pregava. $\mathrm{O}$ pai, em seus sermões, reiterava sua ordem e as proibições, como também o controle das ações da família para manter os costumes. É o que simbolizam essas festas, uma continuidade da tradição. No entanto, dá-se aqui o começo de um rompimento com essa união, o início do desfecho da trama: os sermões do pai penetram nas lembranças de André, Ana rompe a linha da estrutura perpetuada, da continuidade da tradição de regras e comportamento, provocando André com sua sensualidade; André se volta à natureza, se cobrindo de terra úmida e folhas, um retorno a um lugar que não o julgue, isento, puro.

No filme, acontece o mesmo. A família de André e os parentes se encontram no campo, em uma grande roda de dança. André está fora da roda, encostado em uma árvore e observa a festa.

$\mathrm{Na}$ perspectiva dele, uma panorâmica explora o espaço, evocando André, que percorre com um olhar reflexivo todo o espaço da festa, no início da primeira festa da narrativa cinematográfica. Ocorre aos vinte e cinco minutos de filme. O espaço é bastante iluminado, há um jogo de sombra e luz forte destacando a dança. André ainda morava na fazenda, a passagem é sua memória. Ana dança com o irmão Pedro, a música é alegre, festiva, a dança é fraternal, mas, aos poucos, se revela mais sensual, quando ela se mostra para André, e também o olha diretamente. A câmera, em um jogo de campo/contra-campo ${ }^{13}$ (mesmo sem diálogo), fortalece a troca dos olhares e o impacto

\footnotetext{
13 Campo/contra-campo é um procedimento chave num cinema dramático construído dentro dos princípios da identificação. Seu ponto de aplicação máxima se dá na filmagem de diálogos. Ora a câmera assume o ponto de vista de um, ora de outros dos interlocutores, fornecendo uma imagem da cena da alternância de pontos de vista diametralmente opostos (daí a origem da denominação campo/contra-
} 


\section{Revista Leteas Racar}

ISSN: 2317-2347 - v. 7, Edição Especial (2018).

em André. Essa comunhão se expande pelo corpo de André, que se mistura à terra e se cobre de folhas. Nesse momento, o ritmo da filmagem fica mais lento, a música se modifica, tornando-se mais emocional, e a voz off de André (essa voz, como enunciado anteriormente, é do diretor Luiz Fernando Carvalho) narra suas reminiscências, os sentimentos pela irmã. A mãe o enlaça, tentando levá-lo à dança, preocupada com o seu isolamento, mas André permanece afastado em uma contemplação emblemática na figura da irmã.

Retornando ao livro, no capítulo 29, vemos a última festa, que é realizada em função do retorno de André à fazenda. A manhã é clara depois de uma noite escura de seu retorno. A narração retoma com as mesmas palavras da primeira festa. São poucas diferenças, mas extremamente importantes. Agora os verbos são outros, conjugam-se no pretérito perfeito, uma ação acabada no passado, um tempo irreversível "e foi no bosque atrás da casa" (NASSAR, 1989, p. 186). Os personagens têm outra postura frente à dança de Ana, que não é mais inocente, doce, ingênua e aparece "varando com a peste no corpo o círculo que dançava, introduzindo com segurança, ali no centro, sua petulante decadência”. André assiste a essa dança introduzindo os pés na terra úmida, entre folhas secas. Pedro surge sombrio, taciturno, com "os olhos alucinados" procurando o pai e ao encontrá-lo vocifera uma "sombria revelação", e , "para cumprir a trama do seu concerto, o tempo, jogando com requinte, travou os ponteiros" (Ibid., p. 192). Mudanças drásticas acometem a família. Há uma ruptura, ao que já não é mais. Uma festa responsável por marcar o rompimento da família. O pai de posse de um alfanje ceifa a vida "com um só golpe a [da] dançarina oriental” (Ibid., p.192). Seguemse, então, os gritos da família.

O capítulo seguinte, escrito entre parênteses, é, pelo discurso de André, “em memória do pai”. De forma não explicada, o pai morre. Há, também, aqui, um retorno de André, mas diferentemente do retorno anterior, o pai está junto, incrustado em André e contempla o final trágico da família. Por meio da escrita, endereçando ao pai seu discurso "Em memória de meu pai, transcrevo suas palavras", André, enfim, aceitou o pai, aceitou a lei. No filme, esse desfecho se dará de outra forma.

campo). Com esse procedimento, o espectador é lançado para dentro do espaço do diálogo. Ele, ao mesmo tempo, intercepta e identifica-se com duas direções de olhares, num efeito que se multiplica pela sua percepção privilegiada das duas séries de reações expressas na físionomia e nos gestos das personagens (XAVIER, 2005, p. 35). 


\section{Revista Leteas Racar}

ISSN: 2317-2347 - v. 7, Edição Especial (2018).

A sequência acontece em 2h50min de filme. A sonoplastia, na sequência final, comunica-se diretamente com as emoções das personagens e age sobre os sentidos dos espectadores, intensificando a sensibilidade para as tomadas finais: a câmera, em vários planos, ângulos, revela-nos o final trágico de Ana, a família decomposta, a possessão do pai, a solidão de André. Há uma coreografia entre câmera, personagens, natureza, num espaço onde se misturam amor, ódio, paixão, solidão, morte.

A montagem é narrativa, tem por objetivo narrar a ação final da história, o desenrolar de uma sequência de acontecimentos, levando-nos a considerar o filme uma totalidade significativa. A sequência se inicia com uma luz bem forte. A câmera é subjetiva, está na perspectiva de André, ela é o seu olho. Como na festa do início, o plano-sequência se expande para situar o espectador na festa em comemoração à volta de André para casa, ao seio da família. No entanto, nesta festa, entra em cena o irmão, Pedro, que se insere na primeira cena, observando, taciturno, sombrio (ele sabia sobre o incesto entre os irmãos), a dança sensual da irmã dentro da roda de dança. A câmera o focaliza em primeiro plano, deixando a festa em segundo. Nova retomada da câmera na dança, e de repente, há uma ruptura e surge Ana, que dança de forma agressiva, sensual, demonstrando em gestos do corpo a mudança na estrutura da família. Nesse momento, tem-se o rompimento da circularidade. Há, aqui, uma montagem expressiva: a justaposição dos planos entre as imagens exprime uma ideia e produz uma ruptura no pensamento do espectador. Há vários cortes dentro do plano que marcam a finitude do tempo, do pretérito perfeito. Muda o plano, agora fechado, para revelar os pés de André em meio a terra, misturando-se às folhas; muda o ritmo do filme, que se torna mais lento e a voz off de André narra com a mudança do tempo verbal, pretérito perfeito, como no romance. Nesse momento, é memória pura. Nesse quadro, o diretor não revela o corpo de André, só uma parte.

Sobre a relação com a circularidade, retomando a algo que já aconteceu, o próprio Carvalho explica:

Eu sempre pensei na estrutura do Lavoura como sendo uma daquelas pinturas islâmicas em cerâmica, normalmente pinceladas sobre superfícies circulares, um prato, um vaso, onde a cada instante, quase desapercebidamente, surgisse um animal, uma flor, as coisas se revelando e você poderia escolher um ramo novo para seguir a cada instante (CARVALHO, 2002, p. 68). 


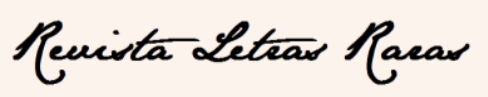

ISSN: 2317-2347 - v. 7, Edição Especial (2018).

No romance, o recurso usado foi o tempo verbal para distinguir as duas festas. No filme, o diretor tinha que mostrar ainda um tempo passado, mas mais trágico, o último. Raduan, no romance, teve o recurso do verbo "era na festa" para indicar a primeira festa, e "foi na festa" para se referir à última. No filme, como Carvalho (2002) explana, essa diferença foi mostrada utilizando outro procedimento, ou seja, o elemento humano para indicar a temporalidade. Na primeira festa, André está encostado em uma árvore, a mesma com que quando criança, brincava, e dali observa a festa ao longe. Em certo momento a mãe sai da roda de dança e chama-o para participar da festividade, e ele diz: "Me deixa, mãe, eu estou me divertindo". André, na primeira festa, aparece e interage com a mãe, criando-se, então, uma relação de espaço. Na segunda, o diretor exclui a imagem de André da festa, seu corpo é representado apenas pelos planos, fechados, em seus pés em meio à terra e às folhas. Seu ponto de vista é privilegiado, "como se apenas sua memória estivesse permanecido naquele tempo" (CARVALHO, 2003, p. 69), sua presença nessa festa tornou-se sensória. Ao eliminar seu corpo, não se constrói uma presença temporal, física e com o poder de impedir a morte da irmã. O diretor trabalhou apenas com a memória de André: com sua presença a leitura da festa se tornaria mais temporal, pois haveria uma presença física, uma atitude, uma ação na sequência, uma cronologia, situando-o. André só é revelado no final da sequência, após a morte de Ana, e, mesmo assim, com o corpo coberto de folhas.

A câmera retorna à Ana, "endiabrada", derrama o vinho em seu corpo, prenunciando aqui o fim trágico, "coalho de sangue". Pedro retorna em cena, dá as costas para a dança, e a câmera, num movimento de travelling vertical, de cima para baixo, para alguns segundos nos seus pés, que estão no chão, na lavoura da fazenda, evidenciando o enorme peso do segredo dos irmãos. Em uma tomada da câmera em seu rosto, percebemos que tomou uma decisão. Dirige-se rapidamente para onde se encontra o pai e lhe revela sobre o incesto. Corte na cena, retoma em André e Ana, no passado, atualizando o incesto, como se fossem as palavras de Pedro revelando o segredo. A imagem escurece, o pai se verte em sombra. Outro corte, e desvela-se o pai, já possesso, derrubando o filho Pedro, e, de posse de um alfanje, mata Ana. Em um grande movimento de personagens, em sucessão de imagens, sem trilha sonora, somente som ambiente com gritos de desespero. Plano das pernas do pai, que, nesse momento, enverga-se em puro instinto. O ritmo agora é outro, deixa de ser lento, a mãe 


\section{Revista Leteas Racar}

ISSN: 2317-2347 - v. 7, Edição Especial (2018).

desesperada tenta impedir, mas Ana é golpeada pelo pai. O pai cai de joelhos, tomadas somente do chão, plano para a flor vermelha, que enfeitava o cabelo de Ana, esfacelada, família destruída. André, finalmente, se revela em meio à natureza, inerte, coberto de folhas. Uma lágrima é derramada, revelando uma solidão absoluta. André confunde-se com as folhas, suas lembranças ratificam a profundidade trágica da existência, do tempo que não volta atrás, de caráter irrecuperável. Nesse último quadro, surge a voz off de Raul Cortez, ator que vive o pai, declamando suas últimas palavras ao som de uma melodia instrumental, triste, trágica:

O tempo é o maior tesouro de que o homem pode dispor, embora inconsumível, o tempo é o nosso melhor alimento. Sem medida que o conheça, o tempo é contudo nosso bem de maior grandeza: não tem começo, não tem fim. Rico não é o homem que coleciona e se pesa num amontoado de moedas, nem aquele devasso que estende mãos e braços em terras largas. Rico só é o homem que aprendeu piedoso e humilde a conviver com o tempo, aproximando-se dele com ternura, não se rebelando contra o seu curso, brindando antes com sabedoria para receber os favores e não a sua ira; o equilíbrio da vida está essencialmente nesse bem supremo, e quem souber com acerto a quantidade de vagar ou de espera que se deve pôr nas coisas não corre nunca o risco ao buscar por elas e defrontar-se com o que não é. Pois só a justa medida do tempo dá a justa natureza das coisas (LAVOURA ARCAICA, 2001).

A câmera subjetiva está em André, que assiste à sua história ao mesmo tempo em que a revive. Essas são as cenas finais da história. As palavras do pai nesse final do filme não correspondem ao último capítulo do romance, elas foram retiradas do capítulo 9, no entanto, o trecho não reproduz continuamente o discurso, há pequenos cortes e mínimas alterações. Essa transferência da voz do filho para o pai deixa subentender que a circularidade permaneceu na família: André retornou à família, dissolvida, e o pai, mesmo após sua morte, ainda tinha a posse da voz, que enredadas na imagem do filho, concretiza-se o retorno circular à família. Nesse final, vemos André coberto de folhas, como em um sepultamento: simbolicamente o homem volta para a terra, morre, e a palavra do pai se impõe, vive, ainda soberana.

O som, nessa última sequência, também foi usado para construir a diferença entre as duas festas. Na primeira, a música é mais alegre, tem um ritmo bem marcado do oriente, é instrumental, marcando bem o momento festivo da ação. Torna-se mais suave somente quando André relata, voz off, seus sentimentos pela irmã, sentado em baixo da 


\section{Revista Leteas Racar}

ISSN: 2317-2347 - v. 7, Edição Especial (2018).

árvore, com os pés mergulhados na terra. Na segunda, a música é uma explosão de instrumentos variados, também lembra o ritmo do oriente, mas é mais agressiva, retumbante, intensa, e também se suaviza quando a voz off de André começa narrar a sensualidade da irmã.

Esses dois momentos da narrativa, inegavelmente, são extremamente importantes, pois a temática da temporalidade se descortina, revelando metaforicamente o embate entre o moderno e o arcaico. Enquanto o pai enaltece o tempo, percebido por ele como se tudo devesse se manter igual, ou em um movimento circular, sempre voltando ao ponto de partida, como vimos na narração do pai, no final do filme, e no capítulo 9, no romance, André o compara ao demônio, como podemos perceber, no romance: "O tempo, o tempo é versátil, o tempo faz diabruras, o tempo brincava comigo" (NASSAR, 1989, p. 95); “o tempo, o tempo, esse algoz às vezes suave, às vezes mais terrível, demônio absoluto" (Ibid., p. 99); também no capítulo 29 do romance, e no filme, antes de iniciar a narração da festa e seu desfecho trágico, André revela a inutilidade de uma luta contra o seu poder:

O tempo e suas águas inflamáveis. Esse rio largo que não cansa de correr, lento e sinuoso. "Ai daquele", dizia o pai: "que tenta deter com a mãos seu movimento, será consumido por suas águas. Ai daquele, aprendiz de feiticeiro, que abre a camisa para o confronto; há de sucumbir em suas chamas". O tempo e suas mudanças, presente em cada sítio, em cada palma, em cada grão, e presente também com seus instantes, em cada letra desta minha história passional, transformando a noite escura do meu retorno, numa manhã cheia de luz (LAVOURA ARCAICA, 2001).

Por isso o tempo é diabólico para André, um tempo que usa as próprias palavras e as ações dos homens para o fundo do poço.

Enfim, não há na montagem das cenas de todo o filme uma continuidade de uma sequência para outra. Carvalho procurou trabalhar com a circularidade, que a obra de Raduan sugere, com o sensorial o tempo todo. Os cortes nos blocos de fluxos de consciência de André são realizados em uma função ligada aos instantes de memória para promover o giro e enredar o espectador pelo transe da narrativa. Cortes bruscos também eram um recurso, como uma linguagem sem parágrafo, um fluxo de pensamentos, como se as rupturas de André fossem rompidas por ele mesmo, em um ir e vir constante. Para André o tempo era "algoz", sem continuidade, mas com 


\section{Reuista Leteas Paear}

ISSN: 2317-2347 - v. 7, Edição Especial (2018).

descobertas e experiências, que também se rompiam, instáveis. Notamos essa descontinuidade nas fusões, nos cortes entre as sequências.

\section{Considerações Finais}

Concluindo esta dupla leitura, entendemos que ambos, romance e filme, têm, nos dramas pessoais, o ingrediente ideal para sustentar a trama, envolvendo o leitor/espectador ao longo da narrativa literária/fílmica. O enredo enfoca um drama comum e perene, o confronto entre desejo e proibição, entre o autoritário e o anárquico que sustenta a narrativa. A força motriz por trás do conflito entre pai e filho, irmão e irmã, tem a ver com as complexas relações humanas. A narrativa de Raduan Nassar tem conotação lírica e trágica, com a morte de Ana, demonstrando que o gênero do romance retoma e amplia os temas universais, clássicos, internalizando as vicissitudes que assolam o ser humano. Em uma visão clássica o ser humano era uma vítima do destino, agora enfrenta conflitos que se originam do ser no mundo, suas paixões.

Enfim, romance e filme foram sucesso porque tratam de temas próprios dos seres humanos. Amor, paixão, relacionamentos afetivos, sentimentos, conflitos e outros assuntos relacionados à condição humana foram abordados de forma realista, refletindose na vida dos leitores e dos espectadores. A adaptação fílmica caracterizou-se como uma obra de arte independente, sem perder os liames essenciais com a obra de Raduan. Carvalho soube explorar com eficácia os temas abordados pelo romancista, estabelecendo perfeito diálogo com o texto de Raduan.

\section{REFERÊNCIAS}

AUMONT, J. et al. A estética do fime. Tradução Marina Appenzeller. Campinas, SP: Papirus, 2007.

BOURNEUF, R.; QUELLET, R. O universo do romance. Tradução José Carlos Seabra Pereira. Coimbra: Almedina, 1976.

CARVALHO, Luiz Fernando. Sobre o filme Lavoura Arcaica. São Paulo: Ateliê Editorial, 2002.

DELEUZE, Gilles. A imagem-tempo. São Paulo: Brasiliense, 2005.

FIORIN, José Luiz. Elementos de análise do discurso. São Paulo: Contexto, 1999 (2009). 


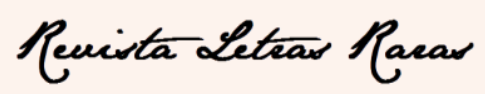

ISSN: 2317-2347 - v. 7, Edição Especial (2018).

JOHNSON, Randal. Literatura e cinema - Macunaíma: do modernismo na literatura ao cinema novo. Trad. de Aparecida de Godoy Johnson. São Paulo: T.A. Queiroz, 1982.

LAVOURA ARCAICA. Direção de Luiz Fernando Carvalho. Brasil: Europa Filmes, 2001. DVD (172 min), son., color. Baseado no romance "Lavoura Arcaica" de Raduan Nassar.

MANZANO, Luiz Adelmo F. Som-imagem no cinema. São Paulo: Perspectiva: FAPESP, 2003.

MARTIN, Marcel. A linguagem cinematográfica. São Paulo: Brasiliense, 2003.

MATTOS, Carlos Alberto. As paredes da casa. In: CARVALHO, Luiz Fernando. Sobre o filme Lavoura Arcaica. São Paulo: Ateliê Editorial, 2002.

MERLEAU-PONTY, Maurice. O cinema e a nova psicologia [tradução de Lino Grunewald]. In: XAVIER, Ismail. A experiência do cinema: antologia. (Org.). Rio de Janeiro: Ediçoes Graal: Embrafilmes, 1983.

NASSAR, R. Lavoura Arcaica. $3^{\text {a }}$ ed. São Paulo: Companhia das letras, 1989.

NUNES, B. O tempo na narrativa. São Paulo: Ática, 1995.

PELLEGRINI, Tânia. [et al.]. Literatura, cinema e televisão. São Paulo: Senac São Paulo: Instituto Itaú Cultural, 2003.

STAM, Robert. Introdução à teoria do cinema. Campinas, SP: Papirus, 2003 (Coleção Campo Imagético).

XAVIER, Ismail. Do texto ao filme: a trama, a cena e a construção do olhar no cinema. In: PELEGRINI, Tania. [et al.]. Literatura, cinema e televisão. São Paulo: Editora Senac e Instituto Itaú Cultural, 2003.

Terra, 2005.

O discurso cinematográfico: a opacidade e a transparência. São Paulo: Paz e

Data de recebimento: $29 / 07 / 2018$

Data de aceite: 25/11/2018 